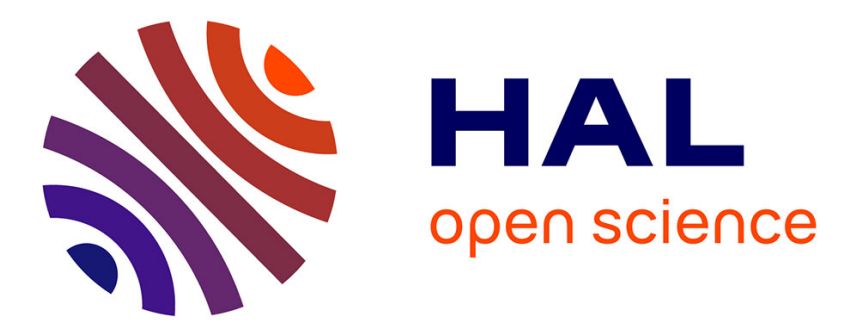

\title{
The symbolism of breast-shaped beads from Dolní Věstonice I (Moravia, Czech Republic)
}

Martina Lázničková-Galetová

\section{To cite this version:}

Martina Lázničková-Galetová. The symbolism of breast-shaped beads from Dolní Věstonice I (Moravia, Czech Republic). Quaternary International, 2019, 503, pp.221 - 232. 10.1016/j.quaint.2017.08.035 . hal-03487162

\section{HAL Id: hal-03487162 \\ https://hal.science/hal-03487162}

Submitted on 20 Dec 2021

HAL is a multi-disciplinary open access archive for the deposit and dissemination of scientific research documents, whether they are published or not. The documents may come from teaching and research institutions in France or abroad, or from public or private research centers.
L'archive ouverte pluridisciplinaire HAL, est destinée au dépôt et à la diffusion de documents scientifiques de niveau recherche, publiés ou non, émanant des établissements d'enseignement et de recherche français ou étrangers, des laboratoires publics ou privés.

\section{다)(1) $(5$}

Distributed under a Creative Commons Attribution - NonCommerciall 4.0 International 
Title: The symbolism of breast-shaped beads from Dolní Věstonice I (Moravia, Czech Republic).

\section{Martina Lázničková-Galetová*}

Key words: personal ornaments - ivory - breast-shaped beads - Gravettian

\section{Summary:}

Eight breast-shaped beads were found variously scattered among differing layers of the Gravettian site, Dolní Věstonice I. Typologically, it is a set of morphologically similar beads of varying sizes made from mammoth ivory with holes for stringing them; one of the pieces was decorated with engraving. Various parts of human body were also found with the artefacts, in a manner typical for this site. The artefacts, however, have no analogies within the Gravettian. The main focus of this will paper will be the manufacturing technology, decoration and possible integration of these variously interpreted artefacts into the Gravettian symbolic system.

* Hrdlička Museum of Man, Faculty of Science, Charles University in Prague, Viničná 7, 128 44 Prague, Czech Republic

**Moravian Museum, Zelný trh 6, 65937 Brno, Czech Republic

***Département de Préhistoire MNHN, UMR 7194, Institut de Paléontologie Humaine, 1 rue René Panhard 75013 Paris, France

\section{Personal address:}

Martina Lázničková-Galetová

Hlinky 72

60300 Brno

Czech Republic

Phone: + 420776170738

E-mail: laznicko@yahoo.fr 


\section{Introduction}

A number of variously designed artefacts made from mammoth ivory were discovered at Dolní Věstonice I, Mammoth ivory, the second most frequent material after clay, was processed at this site into tools, weapons, artefacts of portable art and ornaments (Oliva, 1995; Zelinková, 2007; Valoch and Lázničková-Galetová, 2009). In terms of portable art, the human body or parts of the body were very common at this site, The Venus of Věstonice, a portrait of a woman, human torsos and so on. Personal ormaments also found at the site were similar in form and at the time of their excavation were interpreted as necklaces. (Absolon, 1939; Lázničková-Galetová, 2015). The intensive processing of mammoth ivory, the techniques used, and the economy of using this material are characteristic of this locality; exactly like the repeated depiction of parts of the body. In this paper, the focus will be upon breast-shaped beads - a type of personal ornamentation typical for the Dolní Věstonice I site.

\section{The archaeological and historical context of mammoth ivory artefacts found at Dolní Věstonice I site}

Just as it was with our previous study (Lázničková-Galetová, 2015), the assemblage of 8 ivory artefacts - found during excavations by K. Absolon at Dolní Věstonice in 1937 - was also interpreted as a necklace (Absolon, 1939; 1945) (Fig.1). However, the historical reports from excavation diaries (E. Dania, for comments on the fortunes of Dolní Věstonice collections see Oliva, 2014) and the distribution map of finds that was published at the time do not correspond with each other, nor does it seem likely that the artefacts would be found together. Their positions correspond to a dispersion over 4 metres of the excavation (map by Bohmers, Fig. 2). In the excavation diaries, we do not find reports of all the 8 pieces; the first historical photograph from Absalon's effects has only 7 beads (Fig. 3) - in the documentation from the site, we can only see 4 pieces accounted for. The first complete publication of all these artefacts (Absolon 1939; 1945) shows them threaded on a string, even though 2 of them are not perforated (Fig. 4). Absolon initially was in doubt about how to interpret these artefacts; after the find of a rod with breasts (Absolon's term "hyperstylized Venus XIV") he classed 
these beads as depictions of the upper parts of Venus with emphasized breasts (termed Venus XII) -sexual anatomical carving based on the principle of pars pro toto (Absolon 1939; 1945; 1949). Since Absolon (1939; 1945) states in his publications that the beads are perforated and he always depicts them threaded on a string, this fact is then borrowed by other authors (e.g. Marshack, 1972; Delporte, 1993). Delporte (1993) with depictions including up to 15 beads.

\section{Material and methods}

The eight artefacts (breast-shaped beads) studied, including one decorated with an engraving (Fig. 5) -are made from mammoth ivory. The artefacts are stored in collections in the Anthropos Institute, Moravian Museum in Brno. The documentation dealing with the find contexts of these artefacts has been studied in detail. We used direct observation and microscopy (Leica EZ4HD). For visualisation and subsequent assessment of the state of conservation of artefacts we used non-invasive laboratory-based X-ray microcomputed tomography (microCT). The microCT analysis of these samples was performed using tomography system GE phoenix v|tome|x L240, equipped with a $240 \mathrm{kV} / 300 \mathrm{~W}$ high-power micro focus X-ray tube and flat panel GE DXR detector array. The microCT scan was carried out at $70 \mathrm{kV}$ and $180 \mu \mathrm{A}$ acceleration voltage and X-ray tube current, respectively. X-ray spectrum was modified by $0.1 \mathrm{~mm}$ thick copper filter. The voxel resolution of obtained volume (depending on the object's size) was from $18 \mu \mathrm{m}$ to $12 \mu \mathrm{m}$. Samples were fixed on carbon tube by parafilm (plastic paraffin film). The tomographic reconstruction was done using datos $\mid x 2.03 \mathrm{D}$ computed tomography software. The 3D- and 2D-cross section visualizations were performed with VG Studio MAX 2.2 software.

\section{Results}

\subsection{Description}

The assemblage of 8 breast-shaped beads is standardised in terms of their shape, but not their size (Fig. 6). Their form consists of two spherical to elliptical shapes and a protuberance pointing in the opposite direction. On the back they have an eyelet or a perforation - they have been adapted to be threaded. The material of all artefacts of this series was interpreted as mammoth ivory. 6 beads exhibit an eyelet or a suspension hole. Only a single artefact from this series bears a complex geometric engraving.

\subsection{State of conservation}


In terms of the state of conservation of the artefacts, they exhibit surface cracks in the ivory structure, post-depositional fractures and recent damage. One artefact was found already damaged. According to drawings and comments in the excavation diaries, decorated artefact No. 54 (Fig. 1) was found without the point, which was missing (see drawings and comments

by E. Dania in excavation diaries from Dolní Věstonice). The state of conservation of artefact No. 54 was verified by CT scanning, as it is shown in the image (Fig. 7), the pointed protuberance was repaired using a different material, and the right elliptical projection is cracked along the whole length. Bead No. 57: the section with the perforation was broken off and glued on again. The current state of the surface of artefacts (residues of impression substances, plasticine, varnish layers), conservation method (shellac, varnish), and presence of impression substances for the production of replicas represent the fundamental problems in detailed examination under an optical microscope.

\subsection{Production of breast-shaped beads}

There is only partial information on the processing mammoth ivory for bone industry (Zelinková 2007) and ornaments (Lázničková-Galetová 2015 a, b) at the Dolní Věstonice I site. Regarding the ornaments - breast shaped beads - we know nothing about the shape of ivory débitage products from which the individual segments were made. Uncompleted artifact in ivory at the same site has the same shape but is flat (Fig. 8). Following the natural structure of mammoth ivory we can divide the assemblage of beads into 2 parts - beads which were detached in the longitudinal direction towards the mammoth tusk (No. 52) and those which were detached crosswise (Fig. 9). In this case it cannot be said, as it was with cylindrical beads, that the material detached was used for the production of a series of artefacts. The breast-shaped beads are of variable size.

The use of deeply invasive techniques for shaping is evidenced by the microscopic study of technological marks (Fig. 10). All artefacts except No. 54 are found in various stages of finish; traces of other shaping techniques are not preserved.

\subsubsection{Perforation/eyelet}

Only 6 out of the eight artefacts studied are perforated, 2 pieces are not perforated (No. 51 and No. 56). The latter ones are classed among breast-shaped beads on the basis of similar shape, but they are not adapted for suspension. Because Absolon $(1939 ; 1945)$ in his publications 
always depicted all of these artefacts threaded on a string, the impression arose that all of them are perforated. The hole in all the 6 beads is round, from 1.8 to $4.2 \mathrm{~mm}$ in diameter. In the sample of beads we can recognize 2 technologically different types of suspension perforation and eyelet (Fig. 11). Regarding the perforation (Nos. 50, 55, 54), it is made on the backside of the artefact without any further modification and removal of surrounding material. The backside of perforated beads is flat and angular and in the production sequence it possibly represents a technical interstage before the final formation of the eyelet. The eyelet is semicircular in shape, thick-walled, and after the creation of the initial shape it has been additionally formed (Nos. 57, 52, 53).

\subsubsection{Engraving and finish}

Only a single artefact (No. 54) is decorated with a geometrical engraving, in three other artefacts we can see a deep groove in the middle between the two lobes. This engraving can be either figurative or non-figurative, depending on how the object is interpreted (see Chapter Discussion - Interpretation). In the breast-shaped bead with complex engraving, the engraving is only visible in the front and on the sides of the artefact and consists of groups of short and long, repeating, oblique or straight incisions (Fig. 12). The engraving is axially symmetrical. We do not know whether or not the projection also was engraved, because this part of the bead was repaired with a different material.

\section{Interpretation and function of breast-shaped beads}

The evolution of interpretations of this series of artefacts is long and varied. It is necessary to mention that the objects have no direct analogy in the Palaeolithic. In the excavation diaries from Dolní Věstonice they are recorded as pendants and depictions of human body parts (Absolon's category Venus VII - sexually-biological necklace based on the principle pars pro toto - eight parts). The presence of perforation was surely the reason these artefacts were soon classified as ornaments, more specifically beads, and are still interpreted in this way. Sauter (1944) follows Absolon and classifies these pendants as the earliest stage in the evolution of artefacts called ,,perle à ailette“(winged beads), where the beads from Dolní Věstonice I are considered by him to be prototypes of later, more advanced winged beads. Sauter adds that several authors interpret the Neolithic winged beads as a phallic symbol. The difference 
between winged beads and the breast-shaped beads from Dolní Věstonice is in the different suspension system - winged beads have a perforation in the upper projection, so that the string could be pulled through horizontally, whereas breast-shaped beads have a semi-circular eyelet, through which the string was pulled vertically (Sauter 1944). The system of threading also distinguishes them from other categories of artefacts, such as perforated reindeer teeth and their imitations from various materials, where two teeth attached to each other give a form visually similar to breast-shaped beads. Calegari (1983) classes these beads among bilobate beads or among pendants with gynecomorphic bust (Castiglioni and Calegari 1975). The artefacts are mostly interpreted as a stylised depiction of the female upper body, exactly like the ambiguous rod with breasts (see an overview of interpretations in Nowell and Chang 2014), and even as a self-representation of a woman (McDermott 1996). A. Kehoe (1991), who made suspension experiments with a replica of breast-shaped beads, interprets the artefacts as a depiction of an erect penis with testicles (Fig. 13), exactly like the rod with breasts (Fig. 14). According to Svoboda (Svoboda 1999), these artefacts enable dual interpretation, namely as a schematic female head with breasts and at the same time as the male genital. In this way, Svoboda says, we can also interpret other sexually ambiguous artefacts from Dolní Věstonice, such as the "rod with breasts" or the Venus of Věstonice (Svoboda 2008), and this can symbolize cosmic unity but also a joke or rebus. D. Vialou interprets the decorated breast-shaped bead as a mammoth ivory pendant representing the phallus and vulva. The morphological similarity between the pendants and the rod with breasts (No. 30 003, Absolon's category Venus XIV) from the same material is remarkable, this is the closest analogy among artefacts found in Dolní Věstonice I. According to Absolon (1945), this rod is a degenerated form of Venus which was extremely reduced and whose emphasized breasts symbolise fertility - a sort of "diluvial figural pornography". The rod with breasts has also been interpreted as a stylised male genital (e.g. Nelson 1990). Verpoorte (2001), on the contrary, does not consider the shape of these artefacts a criterion which would class them among human representations - the form is not distinctly human. If we adhere to the hypothesis of depiction of human body - breasts, we come to the problem of depiction of human body parts - segments in the Palaeolithic. Another find from Dolní Věstonice I - a human torso from mammoth ivory (Fig. 15) - also represents an example of depicted human body part. It is flat, displaying a navel and repeated grooves on the back. It is difficult to say whether it is intentional representation of a body part or whether it is only a fragment of depicted human body. This phenomenon is particularly frequent with Dolní Věstonice and Pavlov sites, especially in artefacts from fired clay where it is difficult to 
distinguish between intentional depiction of only a body part, accidental fragmentation of a finished artefact, or even intentional destruction (theory of thermal shock and ritual destruction of clay figurines) (Soffer, Vandiver et al. 1993). The form of breast-shaped beads mimics ,morphologically at least, the shark tooth (Kehoe 1991). Besides Dolní Věstonice I, the teeth of a fossil shark were also found at Pavlov I (Hladilová and Mikuláš, 2005) and they exhibit human use-wear marks. The use of these teeth as personal ornaments is evidenced (Leavesley 2007).

The bird-shaped ornament from Malta (Abramova 1995) is very similar to the morphological structure of breast-shaped beads and it also has a massive eyelet. Other mammoth ivory pendants in the form of flying birds represent a similar morphological structure arranged in a plane. The clay artefact from Krems-Wachtberg (Händel, Simon et al. 2009) also has similar form -2 lobes and a central spike which, however, is not adapted for suspension. The symbols used in mural art, such as the butterfly- or bird-like signs from Chauvet Cave (Züchner 1998), or the breast-like sign from Le Portel (Ariège) (Beltrán, Robert et al. 1966), are also like the morphology of breast-shaped beads. - perforation is ubiquitous in the Upper Palaeolithic. It is found in connection with various materials (mammoth ivory, dentine, bone, antler) and in Dolní Věstonice it occurs either in the form of direct shaping - perforated teeth (e.g. also Lázničková-Galetová 2016), or as a more complicated perforation of cylindrical beads (Lázničková-Galetová 2015). Suspension mechanism in the form of a threedimensional eyelet can in a diachronic comparison be observed rather sporadically - in an Aurignacian mammoth ivory Venus from Hohle Fels (Conard 2009) or in the abovementioned bird from Malta.

Regarding the interpretation of engravings, when we interpret the engraving on the bead No. 54 as a figurative ornament, then the long transverse grooves may represent ornamental or functional bands analogous to the mammoth ivory Venus from Malta (Abramova), and the marl Venus from Kostenki I. The short grooves placed symmetrically in the lower part of both of the hemispherical lobes are interpreted by Oliva (2015) as the depiction of nipples. The small repeating grooves on both sides of the pendant, also analogous to the rod with breasts, can according to some authors represent a tattoo or body painting (the depictions of decoration and tattoo on human bodies were already pointed out by Absolon. Tattoo or body painting might also be depicted on a human torso of mammoth ivory and clay from Dolní Věstonice (Oliva 2015), or on the Venus of Předmostí (D’Errico, Lázničková-Galetová et al. 2011). In the depictions of women in lateral view in Magdalenian bone engravings "Poursuite amoureuse" from Isturitz Cave, the breasts are represented by a series of short, variously 
inclined grooves, or they are decorated with such grooves arranged in bands. Castiglioni and Calegari (Castiglioni and Calegari 1975) interpret these depictions as an example of hypertrichosis. The groove between the lobes is usually referred to as cleavage, but Absolon in this artefact also talks about mons veneris (mons pubis), which in the sense of a visual shortcut is shifted to between the breasts. The experimenter Sonnek (2015), for example, introduces another interpretation - depiction of buttocks with long grooves representing ribbons wound around. He considers the set of segments in general not a necklace, but an erotic tool for men suspended on clothes or worn in a pocket.

If we interpret the series of short incisions on the sides of artefacts as only a non-figurative decor, then it is frequent within the category of personal ornaments such as teeth, beads and pendants (Taborin 1987). The system of short grooves on the sides appears in the Upper Palaeolithic as a decorative pattern on basket-shaped ivory beads, claviform and "doubleolive" pendants (Malerba, Giacobini 2014) in Barma Grande, Arene Candide or Roc-auxSorciers, or on perforated red deer canines (for example Paglicci) or their bone imitations. These have a unilaterally flattened form, which enables to attach two artefacts to one another giving the final visual effect similar to breast-shaped beads. All these types of ornaments, however, differ from the breast-shaped beads fundamentally by a different position of their suspension hole (see above). The same system of incisions - short incisions on the sides and on the face of the artefact - can be observed in a rod with breasts or a gynaecomorphous rod (Venus XIV after Absolon) (Valoch and Lázničková-Galetová 2009). Absolon (1957) counts the groups of grooves, and here also he finds an accordance between the breast-shaped beads and the rod with breasts - the groups of incisions are always multiples of 5, where the bead No. 54 exhibits $2 \times 5$ and $3 \times 5$ short grooves, and the rod with breasts $2 \times 5$ grooves. Within his hypothesis of a Palaeolithic system of notation, Marshack (1972) also counts the incisions on the rod with breasts but comes to different values.

Anthropomorphic representation is a widespread phenomenon in Central European Gravettian (Absolon, 1931; 1939; 2001). Among the most frequent materials used with these artefacts are mammoth ivory and fired clay. They exhibit both identical and different properties which enable the materials to be processed in one or another relevant way. Human body is depicted either complete or in parts, such as torsos, heads, legs or exceptionally breasts. The latter depictions represent isolated body segments - the depicted breasts occur repeatedly, in various size, they are adapted to be worn individually or in series, either on the body or sewn on clothes/accessories or hidden in them, with a high grade of stylisation and symbolical meaning. 


\section{Acknowledgements}

My gratitude for the possibility of studying these artefacts goes to the Moravian Museum. I also thank O. Kroupa for taking photographs, T. Janků for drawings and processing of images, and T. Zikmund from the X-ray micro/nano tomography lab of the Brno University of Technology (CEITEC VUT) for micro-CT scanning. This paper was inspired by the grant of the Czech Science Foundation GAČR 405/10/1710 Upper Palaeolithic Personal Adornments in Moravia: Taphonomical and Technological Analysis.

\section{List of figures:}

1. Breast-shaped beads, photo by O. Kroupa, edited by T. Janků (Moravian Museum Brno).

2. Reconstruction of the context and deposition of the find according to A. Bohmers (Oliva 2015).

3. Historical photograph of artefacts by K. Absolon, edited and modified by T. Janků. Pictured are only 7 out of the currently preserved 8 pieces.

4. Breast-shaped beads threaded on a string (modified after Absolon 1939)

5. Drawing and photos of breast-shaped beads from Dolní Věstonice I (Nos. 50, 57, 55, 51, 56, 52, 54, 53) (T. Janků, Moravian Museum Brno).

6. Graph of dimensions of breast-shaped beads from Dolní Věstonice I.

7. CT-scanning of artefact No. 54 (CEITEC Brno).

8. Uncompleted Artifact in ivory of Dolní Věstonice I.

9. Original position of artefacts with regard to the mammoth tusk (drawing T. Janků, Moravian Museum Brno).

10. Microscopic study of artefact No. 52. a) scraping marks on the eyelet, 18x; b) scraping on the eyelet, around the eyelet, and concentric striations inside, 8x; c) scraping, 16x; d) scraping, 6x; e) polishing at the bottom of the right lobe, 10x.

11. Morphologically different suspension of breast-shaped beads - eyelet (a) No. 57, b) No.52, c) No.53) and perforation (d)- No. 50, e) No. 55, f) No.54).

12. Complex engraving on artefact No.54. Detailed view of short repeating grooves and of the central groove.

13. Experimental suspension of a replica of artefact No. 54, after Kehoe 1991 adapted by T. Janků). 
14. Rod with breasts - gynaecomorphous rod from Dolní Věstonice I (Moravian Museum, photo Moravian Museum).

15. Torso from mammoth ivory, Dolní Věstonice I (drawing T. Janků, Moravian Museum Brno)

\section{References}

Abramova, Z., 1995. L'Art paléolithique d'Europe orientale et de Sibérie. Jérôme Millon, Grenoble.

Absolon, K., 1931. Répresentation idéoplastiques anciennes et nouvelles de femmes du Paléolithique moravien. XVe Congres International d'Anthropologie et d'Archéologique préhistorique, Paris, Paris.

Absolon, K., 1939."Modernist" Moravian Art 30,000 years ago. The Illustrated London News, 467-469.

Absolon, K., 1939. Stylové seskupení fossilních antropomorfních ženských sošek. Anthropologie XVII (1-3), 193-203.

Absolon, K., 1945. Výzkum diluviální stanice lovců mamutů v Dolních Věstonicích na Pavlovských kopcích na Moravě. Pracovní zpráva za třetí rok 1926 Brno, Polygrafie.

Absolon, K., 1949. The diluvial anthropomorphic statuettes and drawings, especially the socalled Venus statuettes, discovered in Moravia: A comparative study. Artibus asiae 12(3), 201-220.

Absolon, K., 1957. Dokumente und Beweise der Fähigkeiten des fossilen Menschen zu zählen im mährischen Paläolithikum. Artibus Asiae 20 (2/3), 123-150.

Beltrán, A., Robert, R., Vézian, J., 1966. La cueva de Le Portel. Monografías arqueológicas I., Zaragoza.

Calegari, G., 1983. "Pendagli bilobati" e "pendagli a punta". Esegesi della problematica ed inventario dei reperti italiani. Atti della Societa Italiana di Scienze Naturali e del Museo Civico di Storia Naturale di Milano Milano 124(1-2), 65-96. 
Castiglioni, O. C., Calegari, G., 1975. I pendagli a busto ginemorfo del paleolitico superiore centro-occidentale europeo, con un inventario ragionato dei reperti italiani.

Conard, J.N., 2003. Palaeolithic ivory scuplptures from southwest Germany and the origins of figurative art. Nature 426.

D`Errico, F., Lázničková-Galetová, M., Caldwell, D. 2011. Identification of a possible engraved Venus from Předmostí, Czech Republic. Journal of Archaeological Science $38(3), 672-683$.

Delporte, H., 1993. L'image de la femme dans l'art paléolithique. Picard éditeurs, Paris.

Händel, M., Simon, U., Einwögerer, T., Neugebauer-Maresch, Ch., 2009. New excavations at Krems-Wachtberg - approaching a well-preserved Gravettian settlement site in the middle Danube region. Quartär 56, 187-196.

Hladilová, Š. Mikuláš, R., 2005. Chapter III.9. Fossil shark tooth, a remarkable working tool from the Pavlov I locality. In: Svoboda, J. A. (Eds), Pavlov I Southeast. A Window Into the Gravettian Lifestyles. Academy of Sciences of the Czech Republic, Institute of Archaeology, Brno, Polish Academy of Sciences, Institute of Systematics and Evolution of Animals, pp. 391-396.

Kehoe, A.C., 1991. No possible, probable shadow of doubt. Antiquity 65, 129-131.

Lázničková-Galetová, M., 2015 a. The phenomenon of Gravettian necklaces - Mammoth ivory necklaces from Dolní Věstonice I (Moravia, Czech Republic). Quaternary International 359-360, 229-239.

Lázničková-Galetová, M. 2015 b. Poznámky k technologii tvorby moravského paleolitického umění. Oliva, M. Umění Moravského paleolitu. Atlas sbírky Ústavu Anthropos Moravského zemského muzea. Studies in Anthropology, Palaeothnology, Plaeontology and Quaternary Geology, vol.38/N.S. 30, Moravské zemské museum, Brno.

Leavesley, M. G., 2007. A shark-tooth ornament from Pleistocene Sahul. Antiquity 81(312): 308-315. 
Malerba, G., Giacobini G., 2014. Les objets en ivoire des sépultures gravettiennes de la Barma Grande de Grimaldi (Ligurie, Italie). Etude descriptive et technologique. L'Anthropologie 118(3): 309-327.

Marshack, A., 1972. Les racines de la civilisation. Plon, Paris.

McDermott, L., 1996. Self-Representation in Upper Paleolithic Female figurine. Current Anthropology 37(2), 227-275.

Nelson, M.S. 1990. Diversity of the Upper Paleolithic "Venus" Figurines and Archaeological Mythology. Archaeological Papers of the American Anthropological Association 2(1), $11-22$.

Nowell, A., Chang, M.L., 2014. Science, the Media, and Interpretations of Upper Paleolithic Figurines. American Anthropologist 116, 562-577.

Oliva, M., 1995. L'usage de l'ivoire au Paléolithique en Tchècoslovaquie. In: Hahn, J., Menu, M., Taborin, Y., Walter, P., Widemann, P., (Eds.), Le travail et l'usage de l'ivoire au Paléolithique supérieur. Actes de la table ronde. Ravello, pp. 189-198.

Oliva, M., 2014. DOLNÍ VĚSTONICE I (1922-1942): Hans Freising - Karel Absolon Assien Bohmers. Moravské zemské muzeum, Brno.

Oliva, M., 2015. Umění Moravského paleolitu. Atlas sbírky Ústavu Anthropos Moravského zemského muzea. Moravské zemské muzeum, Brno.

Sauter, M., R., 1944. Essai sur l'histoire de la perle à ailette. Jahrbuch der Schweizerischen Gesellschaft für Ur- und Frühgeschichte Bd. 35. S. 118f 35, 118-125.

Soffer, O., Vandiver, P., Klíma, B., Svoboda, J., 1993. The Pyrotechnology of Performance Art: Moravian Venuses and Wolverines. In: Knecht H., Pike-Tay, A., White, R., (Eds.), Before Lascaux. The Complex Record of the Early Upper Paleolithic., CRC Press, pp. 259-276.

Sonnek, J., 2015. Od knoflíkové dírky k rozluštění záhady Nazca. Hlučín. 
Svoboda, J.A., 2008. Upper Palaeolithic Female Figurines of Northern Eurasia. In: Svoboda, J.A. (Eds.), Petřkovice - On Shouldered Points and Female Figurines. Academy of Sciences of the Czech Republic, Institute of Archaeology, Brno, pp. 193-223.

Svoboda, J., 1999. Čas lovců, AV ČSAV, Brno.

Taborin, Y., 1987. Le décor des objets de parure. In: Clottes, J., (Dir.), L'art des objets au paléolithique, tome 2, Actes des colloques de la Direction du Patrimoine, Foix - Le Mas d'Azil, pp. 19-38.

Valoch, K., Lázničková-Galetová, M. (Eds.), 2009. The Oldest Art of Central Europe. Moravian Museum, Brno.

Verpoorte, A., 2001. Traces of art, places of fire: a contextual approach to anthropomorphic figurines in the Pavlovian (Central Europe, 29-24 kyr BP). University of Leiden, Leiden.

Zelinková, M., 2007. Industrie z tvrdých živočišných materiálů ze sídliště Dolní Věstonice I. Acta Musei Moraviae, Sciences sociales XCII, 9-51.

Züchner, C., 1998. Grotte Chauvet Archeologically Dated. TRACCE Online Rock Art Bulletin, 12. 

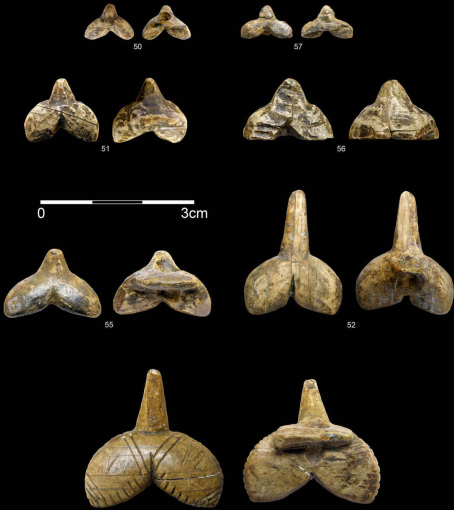

54
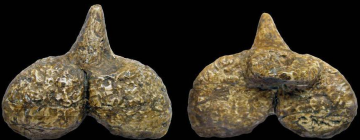


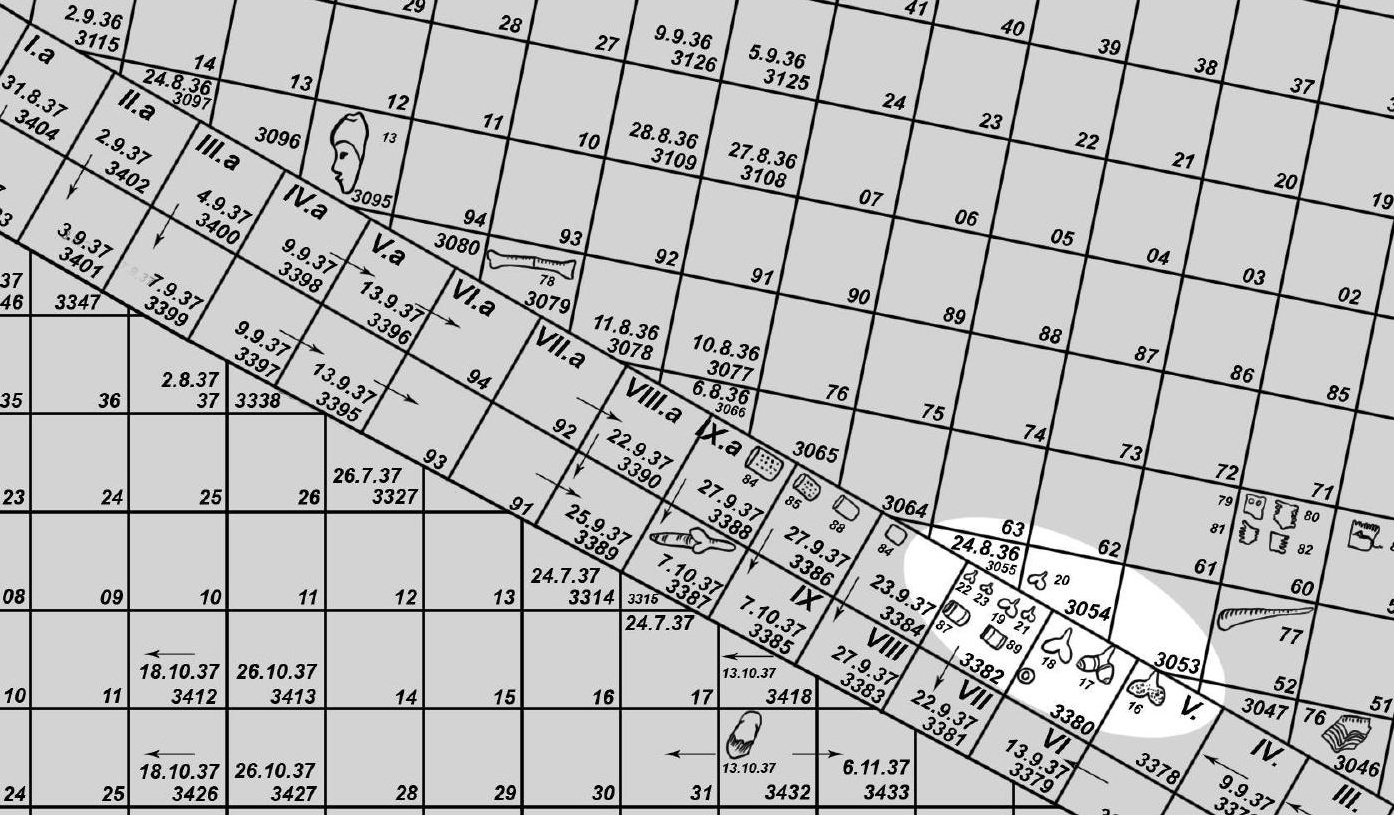



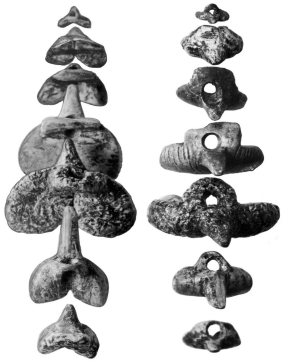
Satacos

0
0

- Ad 4

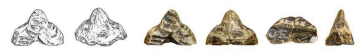

obdhat -.

od bos

do toto 


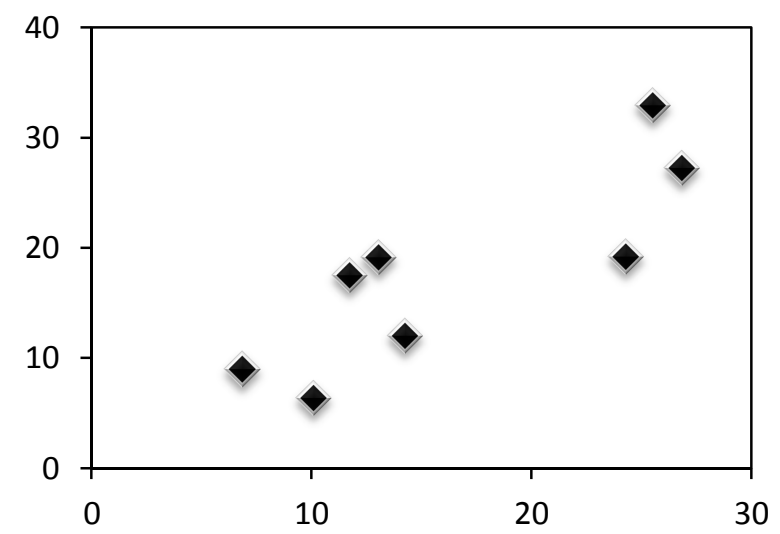



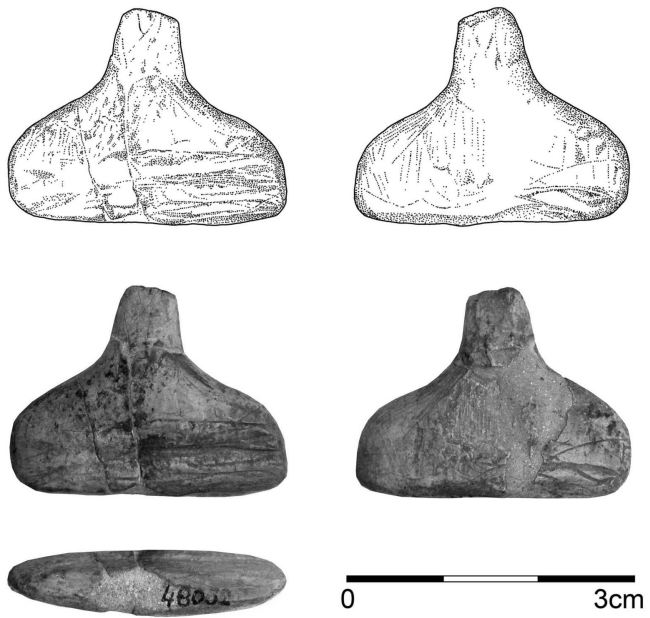

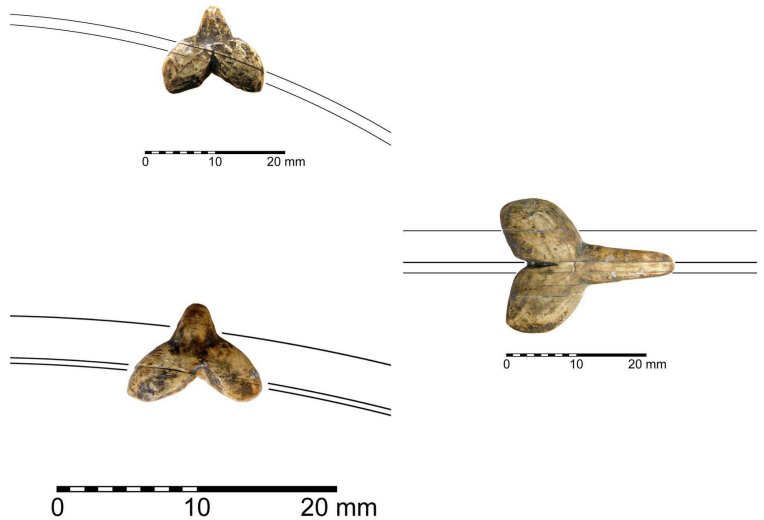

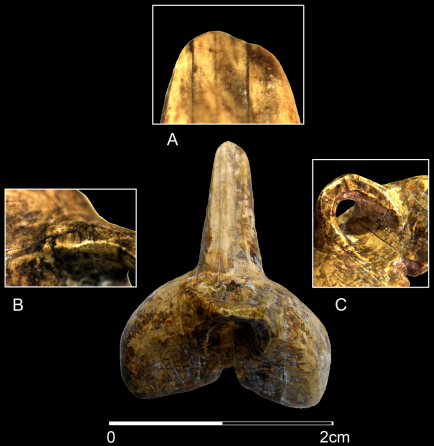

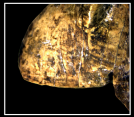

D

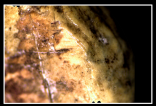

E

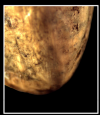

F 


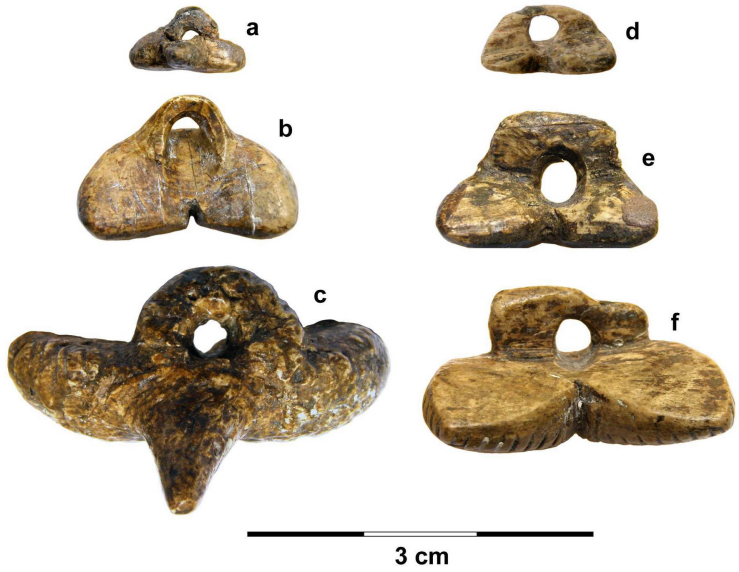



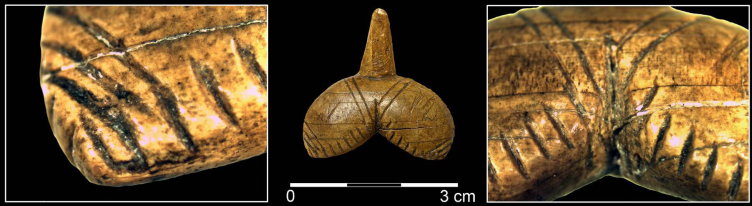

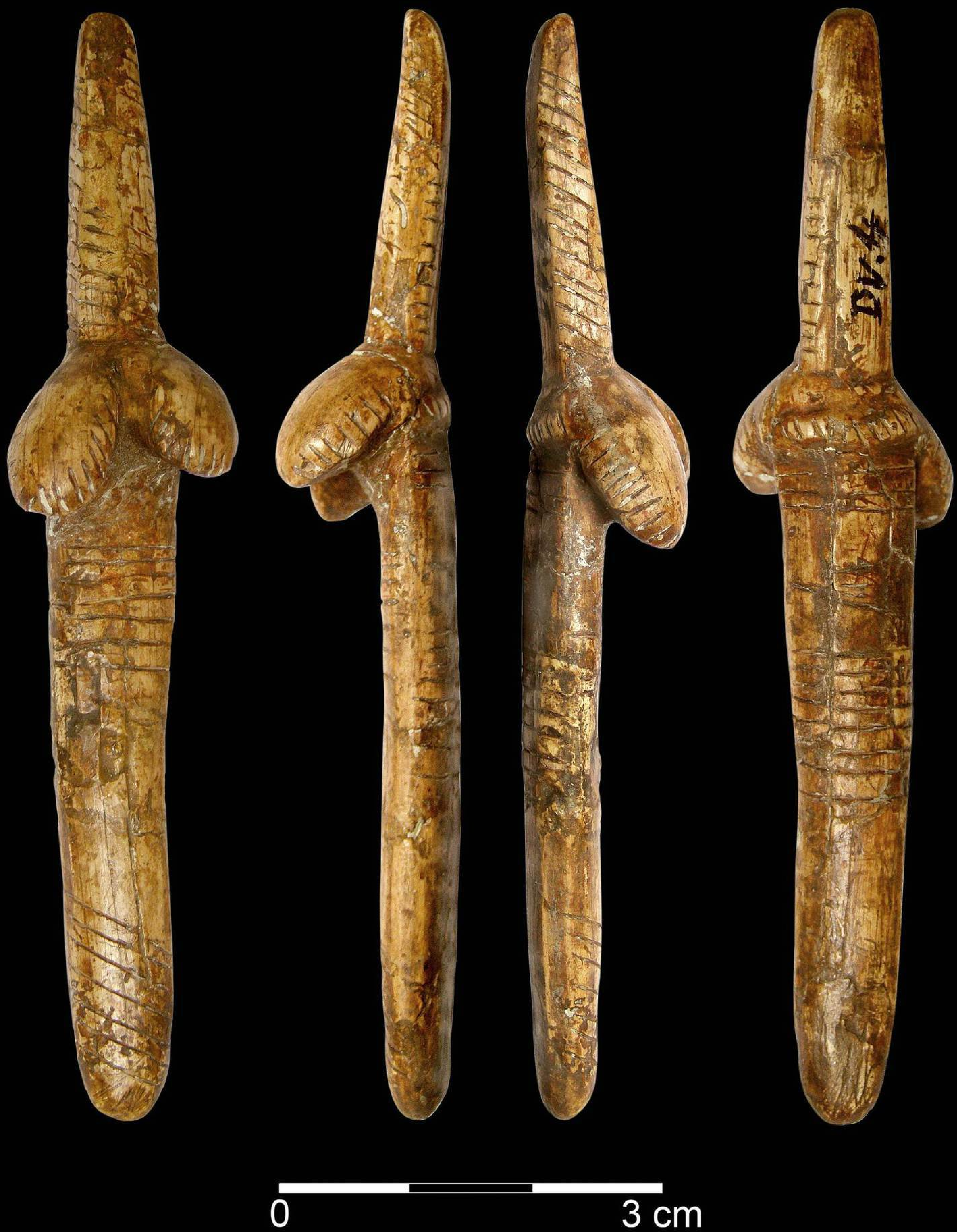

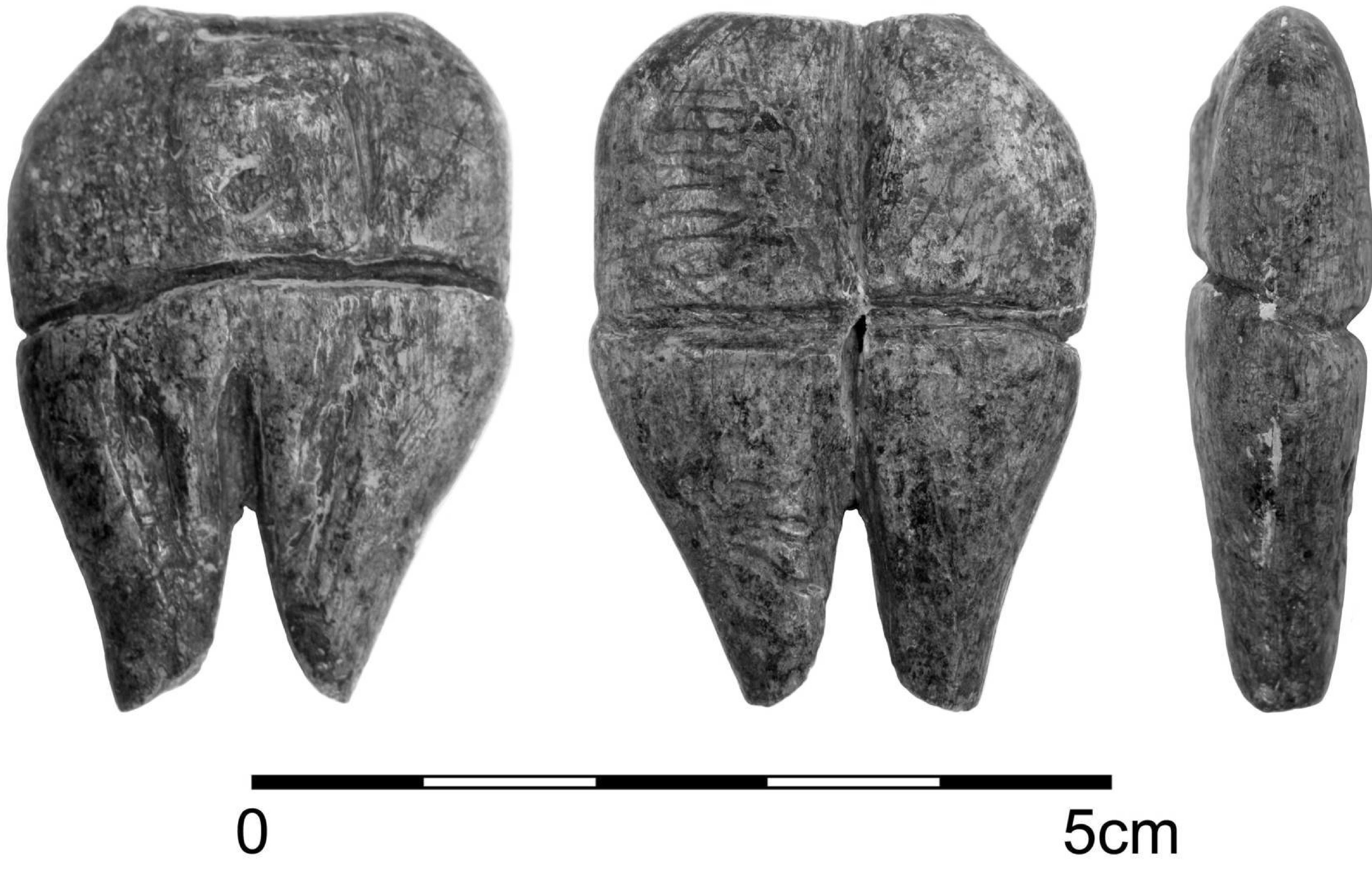

$5 \mathrm{~cm}$ 

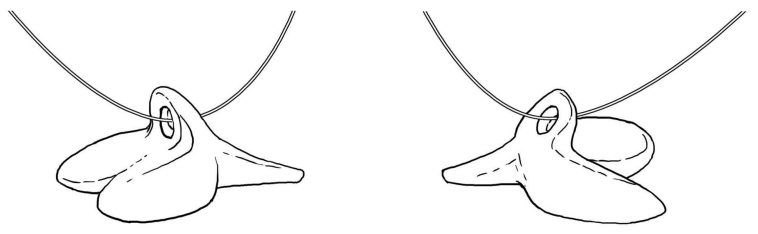